\title{
Treatability tests of synthetic leachate from the Al- Hoceima city controlled landfill
}

\author{
Asmae Charki ${ }^{1 *}$, Hossain El Ouarghi ${ }^{1}$, and M'hamed Ahari ${ }^{2}$ \\ ${ }^{1}$ Water and Environment management Unit, National School of applied sciences, Abdelmalek Essaâdi University, Al \\ Hoceima, Morocco \\ ${ }^{2}$ Laboratory of Research and Development in Engineering Sciences, Faculty of Sciences and techniques, Abdelmalek \\ Essaâdi University, Al Hoceima, Morocco
}

\begin{abstract}
Due to population growth and the intensification of economic activity, the production of solid waste is constantly increasing in Morocco [1]. Several programs consist of the establishment of controlled landfills and the rehabilitation of uncontrolled landfills. The impact of landfilling is the production of liquid effluents rich in organic, mineral, and metallic matter called leachate $[2,3]$. The choice of leachate treatment is based on the characteristics of the leachate. Any treatment process has advantages and limitations, so before proceeding with the treatment it is necessary to characterize the leachate to choose the appropriate process [11]. The objective of this study is to prepare synthetic leachate based on the characteristics of real leachate (case of the controlled landfill of Al Hoceima), in order to carry out treatability tests of this synthetic leachate by controlling the various parameters of analysis. This solution was made from organic $(\mathrm{CH} 3 \mathrm{CO} 2 \mathrm{H}, \mathrm{CH} 3 \mathrm{CO} 2 \mathrm{Na}$ ) and inorganic compounds (MgSO $4, \mathrm{CaCl} 2, \mathrm{Ca}(\mathrm{OH}) 2, \mathrm{NH} 4 \mathrm{Cl}, \mathrm{KOH}, \mathrm{MgCl} 2)$, the various analyzes of this solution gave values comparable to the real solution. This work was devoted to carrying out the treatability tests of synthetic leachate by a process of adsorption on bentonite, by studying its yield to reduce the organic load.
\end{abstract}

\section{KEYWORDS}

Leachate, Synthetic leachate, Characterization, Physico-chemical analyzes, Treatment.

\footnotetext{
* Corresponding author: charki.asmae.ca@gmail.com
} 


\section{Introduction}

The controlled landfill is an ultimate link in any waste treatment sector, it is the place of elimination or storage of the final residues of the refuse treatment chains; if they are well elaborated, and in many situations ; it is still the only form of waste treatment [2]. The production of a liquid effluent rich in organic, mineral, and metallic matter called leachate can be an important impact on landfilling $[3,4]$.

The leachate designates any filtering liquid by percolation through the waste landfilled or contained therein, by being bacteriologically and chemically charged with dissolved and suspended organic and/or mineral substances [5-6], leachate characteristics vary from region to region and seasonally [7]. It must be treated before discharging into the natural environment to avoid environmental and/or health impacts and to meet the requirements of discharge standards [8,9], on the other hand, the continuous production of leachate constitutes a persistent threat to local waters, both surface and deep.

The present study firstly assesses the variation in the characteristics of the leachate from the controlled landfill of $\mathrm{Al}$ Hoceima city and then selects the parameters important for treatment. The objective of this study is to prepare synthetic leachate based on the characteristics of the real leachate from the $\mathrm{Al}$ Hoceima controlled landfill and to perform treatability tests of this leachate by modifying and controlling the analysis parameters, in particular the COD.

\section{Materials and methods}

\subsection{Location and characteristics of the Al Hoceima controlled landfill}

The Al Hoceima controlled landfill is located $6 \mathrm{~km}$ southeast of the city and approximately $3.5 \mathrm{~km}$ northeast of Izafzafene and covers an area of $34 \mathrm{Ha}$, with Lambert coordinates: $X=510000 \mathrm{~m}$ and $\mathrm{Y}=633$ $000 \mathrm{~m}$. It starts working in 2008 and receives 80 t.day $^{-1}$ (140 000 inhabitants) of waste from many urban and rural communities: Al Hoceima, Imzouren, Beni Bouayach, Ait Youssef Ouali, Izmouren, and Ait Kamra (Figure 1).

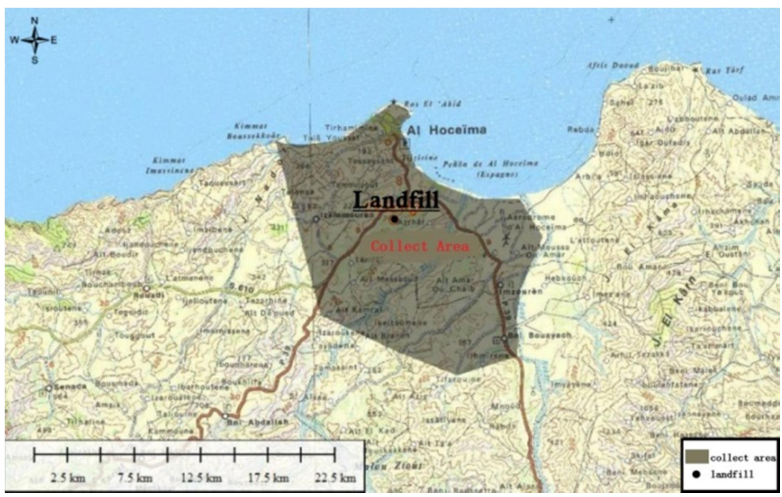

Fig 1: Geographic location of Al Hoceima city controlled landfill.

The landfill is in the Rif area which has a great Mediterranean climatological diversity since there are sub-climates ranging from semi-arid to humid, dry and hot in summer, and rainy and cool in winter. The rainfall is characterized by an irregularity that manifests itself in the amount and intensity of the rains. The site of the landfill shows an absence of groundwater, we note on the site the presence of a temporary pond supplied by runoff collected by a track. In this pond, the water can stay for several months, which attests to the impermeability of the substratum.

\subsection{Characteristics of the Al Hoceima landfill leachate}

Leachate's characteristics are different from one region to others and from landfill to another, they depend on the nature of the waste, the method of exploitation, the age of the waste, and it is also related to seasons. The characterization of the leachate is done by physicochemical analyzes of several parameters; Table 1 presents the characteristics of the leachate from the controlled landfill of $\mathrm{Al}$ Hoceima.

These leachates are characterized by a COD which varies between 12365 and $33600 \mathrm{mg} / \mathrm{L}$, which means that it is young leachate [12], we also note the presence of several important parameters such as chloride which reaches values up to $7196 \mathrm{mg} / \mathrm{L}$, ammonium which varies between 1921 and $4060 \mathrm{mg} / \mathrm{L}$ and an average of $1298.5 \mathrm{mg} / \mathrm{L}$ of nitrates.

Table 1: Characteristics of the $\mathrm{Al}$ Hoceima controlled landfill leachate*

\begin{tabular}{ccccc}
\hline Parameters & Min. & Max. & $\begin{array}{c}\text { Averag } \\
\text { e }\end{array}$ & Unit \\
\hline Temperature & 11.5 & 30.5 & 21.1 & ${ }^{\circ} \mathrm{C}$ \\
pH & 7.2 & 8.6 & 7.9 & $\mathrm{pH}$ \\
Conductivity & 20000 & 37700 & 32933.3 & $\mu \mathrm{s} / \mathrm{cm}$ \\
COD & 12365 & 33600 & 19435.5 & $\mathrm{mg}\left(\mathrm{O}_{2}\right) / \mathrm{L}$ \\
$\mathrm{BOD}_{5}$ & 2881 & 22501 & 9802.2 & $\mathrm{mg}\left(\mathrm{O}_{2}\right) / \mathrm{L}$ \\
Ammonium & 1921 & 4060 & 3184.5 & $\mathrm{mg} / \mathrm{L}$ \\
Nitrite & - & - & 383 & $\mathrm{mg} / \mathrm{L}$ \\
Chloride & 4660 & 7196 & 5691.5 & $\mathrm{mg} / \mathrm{L}$ \\
Nitrate & - & - & 1298.5 & $\mathrm{mg} / \mathrm{L}$ \\
Orthophosphate & - & - & 143 & $\mathrm{mg} / \mathrm{L}$ \\
\hline *Data from the controlled landfill of Al Hoceima city 2013- \\
2018
\end{tabular}




\subsection{Physicochemical analysis}

A sample of leachate solution is taken and diluted according to the range of analysis to be performed. Several parameters are analyzed to get an idea about the characteristics of this leachate. Table 2 summarizes the different parameters analyzed, methods, and techniques used in this study.

Table 2: Methods and techniques used for the characterization of synthetic leachate

\begin{tabular}{|c|c|c|}
\hline Parameter & Units & Method and technique \\
\hline $\mathrm{pH}$ & & $\begin{array}{c}\text { Electrometric measurement (Hach } \\
\text { HQ40d Dual-Input } \\
\text { Multiparameter) }\end{array}$ \\
\hline COD & $\mathrm{mg} \cdot \mathrm{L}^{-1}$ & $\begin{array}{l}\text { HANNA HI } 839800 \text { COD Reactor } \\
\text { AFNOR NFT 90-101 norm }\end{array}$ \\
\hline $\mathrm{BOD}_{5}$ & & OxiTop BOD Measuring System \\
\hline Conductivity & $\underset{1}{\mu \mathrm{s} . \mathrm{cm}^{-}}$ & $\begin{array}{c}\text { Electrical Conductivity (Hach } \\
\text { HQ40d Dual-Input } \\
\text { Multiparameter) } \\
\end{array}$ \\
\hline $\begin{array}{l}\mathrm{NO}_{2}^{-} ; \mathrm{PO}_{4}^{3-} ; \\
\mathrm{NO}_{3}^{-} ; \mathrm{NH}_{4}^{+}\end{array}$ & mg.L. ${ }^{-1}$ & $\begin{array}{l}\text { Molecular Absorption } \\
\text { Spectrometry }\end{array}$ \\
\hline $\mathrm{Cl}^{-}$ & mg.L $L^{-1}$ & $\begin{array}{l}\text { Determination by mercuric nitrate } \\
\text { (Mohr method) }\end{array}$ \\
\hline
\end{tabular}

\subsection{Adsorption treatment}

\subsubsection{Bentonite clay}

In the field of water treatment, adsorption is a technique of choice for the removal of dissolved elements. According to the nature of the forces which maintain the adsorbed molecule on the surface of the solid [14]. It essentially depends on the nature of the solid and the solute. Some solids have adsorbent properties on many bodies [16,17]. Others, on the contrary, have quite marked specificities. Among these adsorbents, we can distinguish activated carbon, cabbage, sawdust, bentonite, etc.

This study is interested in the adsorption on bentonite which is a clay endowed with surface properties. The bentonite used during our work was extracted from the Nador deposit (East region). The physicochemical characteristics and clarifying properties of bentonites of various origins have been the subject of numerous studies [15]. It is characterized by high absorption, ion exchange and swelling capacity, as well as special rheological properties.

\subsubsection{COD reduction test by adsorption in leachate}

Due to the temporal variation of the organic matter contents, we carried out a check of the initial COD concentration of the synthetic leachate to be treated before each experimental test. The initial COD used in all our tests is equal to $32,880 \mathrm{mg} \mathrm{O} 2 / \mathrm{L}$ (close to the maximum value of COD attended in the Al Hoceima controlled landfill).

All adsorption tests were done at room temperature (25

${ }^{\circ} \mathrm{C}$ ) and with raw leachate at $\mathrm{pH}$ 8.4. Due to the high value of COD, the leachate was diluted to $5 \%$. For each COD measurement, a blank test serving as a control (bentonite + distilled water) was carried out in parallel, to be able to calculate the COD at equilibrium.

The percent absorption (or removal rate) of COD is calculated using the following relationship [14]:

$\%$ adsorption $=[(C O D i-C O D e) / C O D i] 100(1)$

CODi: the initial COD $\left(\mathrm{mg} \mathrm{O}_{2} / \mathrm{L}\right)$

CODe: the residual COD $\left(\mathrm{mg} \mathrm{O}_{2} / \mathrm{L}\right)$

\section{Results and discussion}

\subsection{Synthetic leachate}

The synthetic leachate used for the experiments is a fluid synthesized in the laboratory to represent the same physicochemical characteristics of the real leachate from the Al Hoceima controlled landfill. The synthetic leachate used in this study is prepared in the laboratory basing on the concentrations of the compounds used in the study by D. Guyonnet et al. 2005 [13], according to the difference between Moroccan and European leachate, a synthetic leachate concentrated twice more than the Guyonnet's study was prepared. Table 3 below shows the concentrations of the compounds used for the preparation of synthetic leachate.

After preparing the synthetic leachate, and because the COD is a significant parameter for the treatment of leachate, COD analyzes were carried out to check the solution prepared, the following table 3 shows the $1^{\text {st }}$ composition of the synthetic leachate.

Table 3: The components of the first composition of the synthetic leachate

\begin{tabular}{ccc}
\hline \multicolumn{1}{c}{ Components } & Concentration \\
\hline Magnesium chloride & $\mathrm{MgCl}_{2}$ & $1.92 \mathrm{~g} . \mathrm{L}^{-1}$ \\
Potassium hydroxide & $\mathrm{KOH}$ & $1.92 \mathrm{~g} . \mathrm{L}^{-1}$ \\
Ammonium chloride & $\mathrm{NH}_{4} \mathrm{Cl}$ & $5.2 \mathrm{~g} \cdot \mathrm{L}^{-1}$ \\
Acetic acid & $\mathrm{CH}_{3} \mathrm{CO}_{2} \mathrm{H}$ & $3.5 \mathrm{~mL} . \mathrm{L}^{-1}$ \\
Sodium acetate & $\mathrm{CH}_{3} \mathrm{CO}_{2} \mathrm{Na}$ & $4.93 \mathrm{~g} . \mathrm{L}^{-1}$ \\
Calcium hydroxide & $\mathrm{Ca}(\mathrm{OH})_{2}$ & $1.04 \mathrm{~g} . \mathrm{L}^{-1}$ \\
Calcium chloride & $\mathrm{CaCl}_{2}$ & $4.22 \mathrm{~g} \cdot \mathrm{L}^{-1}$ \\
Magnesium sulfate & $\mathrm{MgSO}_{4}$ & $1.2 \mathrm{~g} \cdot \mathrm{L}^{-1}$ \\
\hline
\end{tabular}

Since the real leachate from the Al Hoceima city controlled landfill is characterized by a COD that attends a maximum value of $33600 \mathrm{mg} / \mathrm{L}$, we choose to work with a synthetic leachate which has a COD of $32880 \mathrm{mg} / \mathrm{L}$, the table 4 below shows the composition of the final synthetic leachate which is adjusted to the characteristic of the Al Hoceima city controlled landfill real leachate. 
Table 4: Final composition of Al Hoceima controlled landfill synthetic leachate

\begin{tabular}{ccc}
\hline \multicolumn{1}{c}{ Components } & & Concentration \\
\hline Magnesium chloride & $\mathrm{MgCl}_{2}$ & $1.92 \mathrm{~g} \cdot \mathrm{L}^{-1}$ \\
Potassium hydroxide & $\mathrm{KOH}$ & $1.92 \mathrm{~g} \cdot \mathrm{L}^{-1}$ \\
Ammonium chloride & $\mathrm{NH}_{4} \mathrm{Cl}$ & $5.20 \mathrm{~g} \cdot \mathrm{L}^{-1}$ \\
Acetic acid & $\mathrm{CH}_{3} \mathrm{CO}_{2} \mathrm{H}$ & $3.50 \mathrm{~mL} \cdot \mathrm{L}^{-1}$ \\
Sodium acetate & $\mathrm{CH}_{3} \mathrm{CO}_{2} \mathrm{Na}$ & $4.93 \mathrm{~g} \cdot \mathrm{L}^{-1}$ \\
Calcium hydroxide & $\mathrm{Ca}(\mathrm{OH})_{2}$ & $1.04 \mathrm{~g} \cdot \mathrm{L}^{-1}$ \\
Calcium chloride & $\mathrm{CaCl}_{2}$ & $4.22 \mathrm{~g} \cdot \mathrm{L}^{-1}$ \\
Magnesium sulfate & $\mathrm{MgSO}_{4}$ & $1.20 \mathrm{~g} \cdot \mathrm{L}^{-1}$ \\
Potassium dihydrogen & $\mathrm{KH}_{2} \mathrm{PO}_{4}$ & $0.10 \mathrm{~g} \cdot \mathrm{L}^{-1}$ \\
phosphate & & $2.12 \mathrm{~g} \cdot \mathrm{L}^{-1}$ \\
Potassium nitrate & $\mathrm{KNO}_{3}$ & $0.58 \mathrm{~g} \cdot \mathrm{L}^{-1}$ \\
Sodium nitrate & $\mathrm{NaNO}_{2}$ & $3.0 \mathrm{~g} \cdot \mathrm{L}^{-1}$ \\
Glucose & $\mathrm{C}_{6} \mathrm{H}_{12} \mathrm{O}_{6}$ & \\
& & \\
\hline
\end{tabular}

After preparing the last composition of the synthetic leachate, physicochemical analyzes were carried out to characterize this synthetic leachate and make a comparison with the real leachate from the controlled landfill of Al Hoceima city.

Analyzes of COD, chloride, ammonium, nitrites, nitrates, and phosphorus were carried out, the results of the analyzes were close to those of the real leachate from the controlled landfill of Al Hoceima, Table 5 presents the characteristics of the synthetic leachate.

Table 5: Characteristics of the synthetic leachate of the Al Hoceima controlled landfill

\begin{tabular}{ccc}
\hline Parameters & Average & Unit \\
\hline Temperature & 27 & ${ }^{\circ} \mathrm{C}$ \\
$\mathrm{pH}$ & 8.5 & $\mathrm{pH}$ \\
Conductivity & 13000 & $\mu \mathrm{s} / \mathrm{cm}$ \\
$\mathrm{COD}$ & 32880 & $\mathrm{mg}\left(\mathrm{O}_{2}\right) / \mathrm{L}$ \\
$\mathrm{BOD}_{5}$ & 4000 & $\mathrm{mg}\left(\mathrm{O}_{2}\right) / \mathrm{L}$ \\
Ammonium & 2159 & $\mathrm{mg} / \mathrm{L}$ \\
Nitrite & 535.7 & $\mathrm{mg} / \mathrm{L}$ \\
Chloride & 7400 & $\mathrm{mg} / \mathrm{L}$ \\
Nitrate & 1330 & $\mathrm{mg} / \mathrm{L}$ \\
Orthophosphate & 425 & $\mathrm{mg} / \mathrm{L}$ \\
\hline
\end{tabular}

The characteristics of the synthetic leachate are variables; we can change them as we need. In this study, we choose the maximum value of COD to study the yield of treatment by adsorption on this leachate.

\subsection{Treatability test of synthetic leachate using adsorption process}

\subsubsection{Adsorption on bentonite}

For the adsorption tests, the bentonite was washed with distilled water, filtered through a Büchner funnel, and dried in an oven at $100^{\circ} \mathrm{C}$ until a powder was obtained [14]. For the first bentonite adsorption treatment tests, we studied the adsorption yield as a function of stirring time.

\subsubsection{Adsorption as function of stirring time}

We prepared 5 pairs of $100 \mathrm{ml}$ samples of $5 \%$ diluted synthetic leachate; $0.5 \mathrm{~g}$ of bentonite was added to the samples. The first pair was stirred for $30 \mathrm{~min}$, the second pair stirred for 1 hour, the third for 2 hours, the fourth for 3 hours, and the last pair was stirred for 4 hours. A blank test (distilled water $+0.5 \mathrm{~g}$ of bentonite) was prepared in parallel with each pair of samples to calculate the COD at equilibrium. All samples were left to stand for 24 hours. The following table 6 shows the results of this experience.

Table 6: The influence of stirring time on COD adsorption yield using $5 \mathrm{~g} / \mathrm{L}$ of bentonite.

\begin{tabular}{c|cc}
\hline Stirring time $(\mathrm{h})$ & $\begin{array}{c}\text { Initial COD } \\
(\mathrm{mg} / \mathrm{L})\end{array}$ & $\begin{array}{c}\text { Residual COD } \\
(\mathrm{mg} / \mathrm{L})\end{array}$ \\
\hline 0,5 & 32880 & 21360 \\
\hline 1 & 32880 & 21200 \\
\hline 2 & 32880 & 21120 \\
\hline 3 & 32880 & 20160 \\
\hline 4 & 32880 & 19200 \\
\hline
\end{tabular}

According to table 6, we realize that the stirring time does not make this big difference in the COD adsorption yield. The adsorption percentage varies from $35 \%$ for $30 \mathrm{~min}$ of stirring to $41.6 \%$ for 4 hours of stirring. After these results, we decided to study the effect of the mass of bentonite on the adsorption yield.

\subsubsection{Adsorption as a function of the bentonite mass}

5 pairs of $100 \mathrm{ml}$ samples of $5 \%$ diluted synthetic leachate were prepared, $0.2 \mathrm{~g}$ of bentonite was added to the first pair, $0.5 \mathrm{~g}$ of bentonite to the $2 \mathrm{nd}$ pair, $1 \mathrm{~g}$ of bentonite to the $3 \mathrm{rd}$ pair and $1.5 \mathrm{~g}$ and $2 \mathrm{~g}$ to 4 th and last pair of synthetic leachate samples. A blank test (distilled water + bentonite) was prepared in parallel with each pair of samples with the same mass of bentonite in order to be able to calculate the COD at equilibrium. All samples were left to stand for 24 hours. The following table 7 presents the adsorption yield on COD using bentonite clay.

Table 7: The COD adsorption yield using different mass of bentonite.

\begin{tabular}{cccc}
\hline $\begin{array}{c}\text { Mass of } \\
\text { bentonite }(\mathrm{g})\end{array}$ & $\begin{array}{c}\text { Stirring } \\
\text { time }(\mathrm{h})\end{array}$ & $\begin{array}{c}\text { Initial COD } \\
(\mathrm{mg} / \mathrm{L})\end{array}$ & $\begin{array}{c}\text { Residual COD } \\
(\mathrm{mg} / \mathrm{L})\end{array}$ \\
\hline 0,2 & 1 & 32880 & 28800 \\
\hline 0,5 & 1 & 32880 & 24000 \\
\hline 1 & 1 & 32880 & 21600 \\
\hline 1,5 & 1 & 32880 & 19800 \\
\hline 2 & 1 & 32880 & 19200 \\
\hline
\end{tabular}

From the previous table 7 the adsorption yield of the COD varies by varying the mass of bentonite added. the adsorption percentage is respectively $12.4 \%, 27 \%$, $34.3 \%, 39.7 \%$ and $41.6 \%$ for the $100 \mathrm{ml}$ samples of the synthetic leachate of $0.2 \mathrm{~g}, 0.5 \mathrm{~g}, 1 \mathrm{~g}, 1.5 \mathrm{~g}$ and $2 \mathrm{~g}$ of bentonite.

\subsubsection{COD adsorption yield using bentonite clay}

After studying the impact of the mass of bentonite added and the stirring time on the COD adsorption yield in the synthetic leachate, it was decided to increase the stirring time by using two different masses of bentonite. 
2 pairs of $100 \mathrm{ml}$ samples of $5 \%$ diluted synthetic leachate were prepared, $0.5 \mathrm{~g}$ of bentonite was added to the first pair of samples and $2 \mathrm{~g}$ of bentonite to the 2nd pair, A blank test (distilled water + bentonite) was prepared in parallel with each pair of samples with the same mass of bentonite to be able to calculate the COD at equilibrium. All samples were stirred for 24 hours and left to stand for 24 hours. The following table 8 shows the COD adsorption yield of this experience.

Table 8: COD adsorption yield in synthetic leachate using bentonite clay.

\begin{tabular}{cccc}
\hline $\begin{array}{c}\text { Mass of } \\
\text { bentonite } \\
(\mathrm{g})\end{array}$ & $\begin{array}{c}\text { Stirring } \\
\text { time }(\mathrm{h})\end{array}$ & $\begin{array}{c}\text { Initial COD } \\
(\mathrm{mg} / \mathrm{L})\end{array}$ & $\begin{array}{c}\text { Residual } \\
\mathrm{COD} \\
(\mathrm{mg} / \mathrm{L})\end{array}$ \\
\hline 0,5 & 24 & 32880 & 16320 \\
\hline 2 & 24 & 32880 & 12960
\end{tabular}

From tables 8, 7, and 6 , we can see that the COD adsorption yield has been increased by changing the mass of bentonite added and the time of stirring. It was increased for $5 \mathrm{~g} / \mathrm{L}$ of bentonite from $41.6 \%$ in 4 hours to $50.4 \%$ in 24 hours and for $20 \mathrm{~g} / \mathrm{L}$ of bentonite in 1 hour from $41.6 \%$ to $60.6 \%$ in 24 hours.

\section{Conclusion}

Synthetic leachate prepared from the characteristics of real leachate (the case of the controlled landfill in the city of Al Hoceima) has physicochemical characteristics very close to those of real leachate, in this study we were interested in the COD, to carry out treatability tests we chose the maximum value for the actual leachate $33600 \mathrm{mg} / \mathrm{L}$, and we prepared the synthetic leachate with a COD of $32880 \mathrm{mg} / \mathrm{L}$, this choice was made to evaluate the performance of treatability tests using adsorption on bentonite clay. after performing several treatability tests by varying the amount of bentonite added and the stirring time, we noticed that the yield increases by increasing the stirring time up to 24 hours, when there was no remarkable difference in increasing the mass of bentonite or increasing the stirring time from 1 hour to 4 hours.

The adsorption yield of COD on bentonite reaches up to $60.6 \%$ for $20 \mathrm{~g} / \mathrm{L}$ of bentonite stirred for 24 hours while it does not exceed $41.6 \%$ by increasing the mass of bentonite added.

\section{References}

1. S. Saadi, M. Sbaa, M. El Kharmouz, Caractérisation physico-chimique de lixiviats du centre d'enfouissement technique de la ville d'Oujda (Maroc Oriental), Science Lib., Editions Mersenne, 5 (2013) 1-12.

2. H. Jupsin, E. Praet, J. L. Vasel, Sanitary landfill characterization and modelisation of their evolution, Proceedings of international symposium on environmental pollution control and waste management, 7-10 January 2002, Tunis (Epcowm'2002), 884-896.

3. A. Chofqi, A. Younsi, E. Lhadi, J. Mania, J. Mudry, A. Veron, Environemental impact of an urban landfi 11 on a coastal aquifer (El Jadida, Morocco). J. Afr. Earth Sci. 39 (2004) 509-516.

4. J. Y. M. Alkassasbeh, L. Y. Heng, S. Surif, Toxicity testing and the effect of landfill leachate in Malaysia on behaviour of common carp, Am. J. Environ. Sci. 5 (2009) 209-217.

5. B. Jaskelevicius, V. Lynikien, Investigation of influence of lapes landfill leachate on ground and surface water pollution with heavy metals. J. Environ. Eng. Landsc. Manag. 17 (2009) 131-139.

6. J. Schwarzbauer, S. Heim, S. Brinker, et al. Occurrence and alteration of organic contaminants in seepage and leakage water from a waste deposit landfill, Water Resources 36 (2002) 2275-2287.

7. A.A. Tatsi, A.I. Zouboulis, A field investigation of the quantity and quality of leachate from a municipal solid waste landfill in a Mediterranean climate (Thessaloniki, Greece), Adv. Environ. Res. 6 (2002) 207219.

8. D. Kulikowska, E. Klimiuk, The effect of landfill age on municipal leachate composition, Bioresour. Technol. 99 (2008) 5981-5985.

9. D. Trebouet, A. Berland, J. P. Schlumpf, P. Jaouen, F. Quemeneur, Traitement de lixiviats stabilisés de décharge par des membranes de nanofltration. Revue des sciences de l'eau / Journal of Water Science, 11 (1998) 365-382.

10. E. Diamadopoulos, Characterization and treatment of recirculation-stabilized leachate, Wat. Res., 28 (1994) 2439-2445.

11. S. Renou, J.G. Givaudan, S. Poulain, F. Dirassouyan, P. Moulin, Landfill leachate tratment : Review and opportunity, J. Hazard. Mater. 150 (2008) 468-493.

12. H. Alvarez-Vazquez, B. Jefferson, S.J Judd, Membrane bioreactors vs conventional biological treatment of landfill leachate: a brief review, J. Chem. Technol. Biot. 79 (2004) 1041-1049.

13. D. Guyonnet, E. Gaucher, H. Gaboriau, C.-H. Pons, C. Clinard, V. Norotte, G. Didier, Geosynthetic clay liner interaction with leachate: correlation between permeability, microstructure, and Surface Chemistry, J. Geotech. Geoenviron. Eng. 131 (2005) 740749.

14. T. Bennama, A. Younsi, Z. Derriche, A. Debab, Characterization and physicochemical treatment of El-Kerma (Algeria) landfill leachates by batch adsorption on untreated and chemically activated sawdust, Water Qual. Res. J. Can. (2010) · Volume 45, No. 1, 81-90. 
15. Z. Meçabih, S. Kacimi, B. Bouchikhi, Adsorption des matières organiques des eaux usées urbaines sur la bentonite modifiée par $\mathrm{Fe}(\mathrm{III}), \mathrm{Al}(\mathrm{III})$ et $\mathrm{Cu}(\mathrm{II})$. Revue des sciences de l'eau / Journal of Water Science, 19(1), (2006), 23-31.

16. Z. Dali-Youcef, H. Bouabdasselem N. Bettahar, Élimination des composés organiques par des argiles locales, C. R. Chimie 9 (2006) 1295-1300.

17. B. Benguella, A. Yacouta-Nour, Elimination des colorants acides en solution aqueuse par la bentonite et le kaolin, C. R. Chimie 12 (2009) $762 \mathrm{e} 771$. 